\title{
A liver metalloendopeptidase which degrades the circulating hypotensive peptide hormones bradykinin and atrial natriuretic peptide
}

\section{K.M. Carvalho ${ }^{1,2}$, R.A. Nava ${ }^{1}$, M.S.F. França ${ }^{1}$, M.A.S. Medeiros ${ }^{1}$, G.C. Camarão ${ }^{1}$ and L. Juliano ${ }^{3}$}

\author{
${ }^{1}$ Laboratório de N eurobiologia Molecular Humana, \\ Departamento de Fisiologia e Farmacologia, Faculdade de Medicina, \\ Universidade Federal do Ceará, Fortaleza, CE, Brasil \\ 'Laboratório de Toxinas (LABTOX), D epartamento de Ciências Fisiológicas, \\ Centro de Ciências da Saúde, U niversidade Estadual do Ceará, Fortaleza, CE, Brasil \\ ${ }^{3}$ Departamento de Biofísica, Universidade Federal de São Paulo, SP, Brasil
}

\section{Correspondence \\ K.M. Carvalho \\ Laboratório de Neurobiologia \\ Molecular Humana, Departamento \\ de Fisiologia e Farmacologia, \\ Faculdade de Medicina, UFCE \\ Rua Cel. Nunes de Melo, 1127 \\ 60430-270 Fortaleza, CE \\ Brasil}

Presented at the XIII Annual Meeting of the Federação de Sociedades de Biologia Experimental, Caxambu, MG, Brasil, August 26-29, 1998.

Research supported by CNPq, FINEP, FUNCAP, FAPESP and CAPES.

Received April 14, 1998 Accepted October 26, 1998

\begin{abstract}
A new metalloendopeptidase was purified to apparent homogeneity from a homogenate of normal human liver using successive steps of chromatography on DEAE-cellulose, hydroxyapatite and Sephacryl $\mathrm{S}-200$. The purified enzyme hydrolyzed the $\mathrm{Pro}^{7}-\mathrm{Phe}^{8}$ bond of bradykinin and the $\mathrm{Ser}^{25}-\mathrm{Tyr}^{26}$ bond of atrial natriuretic peptide. No cleavage was produced in other peptide hormones such as vasopressin, oxytocin or Met- and Leu-enkephalin. This enzyme activity was inhibited by $1 \mathrm{mM}$ divalent cation chelators such as EDTA, EGTA and $o$-phenanthroline and was insensitive to $1 \mu \mathrm{M}$ phosphoramidon and captopril, specific inhibitors of neutral endopeptidase (EC 3.4.24.11) and angiotensin-converting enzyme (EC 3.4.15.1), respectively. With $\mathrm{M}_{\mathrm{r}} 85 \mathrm{kDa}$, the enzyme exhibits optimal activity at $\mathrm{pH}$ 7.5. The high affinity of this endopeptidase for bradykinin $(\mathrm{Km}=10 \mu \mathrm{M})$ and for atrial natriuretic peptide $(\mathrm{Km}=5 \mu \mathrm{M})$ suggests that it may play a physiological role in the inactivation of these circulating hypotensive peptide hormones.
\end{abstract}

Key words

- Liver metalloendopeptidase

- Bradykinin

- Atrial natriuretic peptide
The circulating peptide hormones bradykinin $(\mathrm{BK})$ and atrial natriuretic peptide (ANP) are very powerful vasodilators that may participate in the physiological control of arterial pressure (1-5). In the blood, BK is generated from circulating high- and lowmolecular-weight kininogens chiefly by plasma kallikein (4), and ANP is secreted primarily by atrial myocytes in response to local wall stretching (5). Therefore, inactivation of these peptides by the action of degrading enzymes could be involved in the regulation of blood pressure $(6,7)$. Circulat- ing BK may be inactivated by a variety of peptidases including aminopeptidases, carboxypeptidases $\mathrm{N}$ and $\mathrm{M}$, angiotensin-converting enzyme (ACE; EC 3.4.15.1), neutral endopeptidase (NEP; EC 3.4.24.11) and a liver bradykinin-inactivating endopeptidase similar to the thimet-endopeptidase (EC 3.4.24.15) $(4,6,7)$. Circulating ANP may be inactivated by NEP and receptor-mediated clearance. However, several lines of evidence suggest that the metabolism of BK and ANP in vivo is not yet completely understood, and that other metabolic pathways 
Table 1 - Purification of human liver metalloendopeptidase.

The enzyme activity was determined in 10- $\mu$ l aliquots from each chromatography step using Abz-R-P-P-G-F-S-P-F-R-EDDnp as substrate in a final volume of $500 \mu 50 \mathrm{mM}$ Tris- $\mathrm{HCl}$ buffer, $\mathrm{pH} 7.5$, at $37^{\circ} \mathrm{C}$. Hydrolysis of the substrate was monitored by measuring the fluorescence at $\lambda_{\mathrm{em}}=420 \mathrm{~nm}$ and $\lambda_{\mathrm{ex}}=320 \mathrm{~nm}$ in a Shimadzu Model F 2000 spectrofluorometer.

\begin{tabular}{|c|c|c|c|c|c|}
\hline Step & $\begin{array}{l}\text { Total protein } \\
\text { (mg) }\end{array}$ & $\begin{array}{l}\text { Total activity } \\
\text { (nmol/h) }\end{array}$ & $\begin{array}{l}\text { Specific activity } \\
\left(\mathrm{nmol} \mathrm{h} \mathrm{h}^{-1} \mathrm{mg}^{-1}\right)\end{array}$ & $\begin{array}{l}\text { Purification } \\
\text { (fold) }\end{array}$ & $\begin{array}{c}\text { Yield } \\
(\%)\end{array}$ \\
\hline Homogenate & 23478 & 21168 & 0.90 & 1 & 100 \\
\hline Supematant & 1826.07 & 8674.80 & 4.75 & 5.3 & 40.98 \\
\hline DEAE-Trisacryl & 504.34 & 5030.40 & 9.97 & 11.1 & 23.76 \\
\hline Hydroxyapatite & 0.86 & 112.15 & 130.40 & 145 & 0.52 \\
\hline Sephacryl S-200 & 0.34 & 78.67 & 231.38 & 257 & 0.37 \\
\hline
\end{tabular}

may also participate in their physiologial inactivation. Thus, although several studies have shown that coadministration of NEP and clearance receptor inhibitors produces a greater diuresis, natriuresis and depressor arterial pressure response, probably reflecting accumulation of endogenous ANP in target tissues (8-12), these responses were not sustained $(13,14)$. Furthermore, the lack of therapeutic efficacy in long-term treatment for hypertension by these inhibitors suggests that ANP may also be inactivated by other important elimination pathways $(10,14)$. Finally, new ANP-degrading enzymes which are resistant to NEP inhibitors were isolated from vascular smooth muscle (15), bovine kidney (16) and human neuroblastoma (17).

In the present study, a new metalloendopeptidase which hydrolyzes BK and ANP with $\mathrm{Km}$ values at micromolar concentrations was purified and characterized from the homogenate of normal human liver.

The livers were obtained from three apparently normal subjects ( 6 to $8 \mathrm{~h}$ after death in traffic accidents) aged 20 to 30 years, and kept at $-80^{\circ} \mathrm{C}$, homogenized in 4 volumes $(\mathrm{w} /$ v) of $50 \mathrm{mM}$ Tris- $\mathrm{HCl}, \mathrm{pH} \mathrm{7.5,} \mathrm{and} \mathrm{centri-}$ fuged at $25,000 \mathrm{~g}$ for $60 \mathrm{~min}$ at $4^{\circ} \mathrm{C}$. The pellet was discarded and the supernatant was exhaustively dialyzed against the same buffer as used for liver homogenization. A volume of 1 liter of the dialyzed supernatant was applied to a DEAE-Trisacryl column (2.6 x $50 \mathrm{~cm}$; Pharmacia, Uppsala, Sweden) equilibrated with $50 \mathrm{mM}$ Tris- $\mathrm{HCl}, \mathrm{pH} 7.5$, at a flow rate of $85 \mathrm{ml} / \mathrm{h}$. After sample application, the column was developed with step gradients of $50 \mathrm{mM}$ Tris- $\mathrm{HCl}$, $\mathrm{pH} 7.5$, containing $\mathrm{NaCl}$ at the following concentrations: 50, 100, 150, 300 and $1000 \mathrm{mM}$. The fractions eluted with $50 \mathrm{mM} \mathrm{NaCl}$ containing the enzyme activity were pooled and concentrated to $8 \mathrm{ml}$ in a dialysis tube under reduced pressure. This sample was exhaustively dialyzed against $10 \mathrm{mM}$ potassium phosphate, $\mathrm{pH} 7.5$, and applied to a hydroxyapatite column $(2.5 \times 10 \mathrm{~cm}$; IBF, Villeneuve-La-Garenne, France) equilibrated with the same buffer. The column was eluted with a $10-500 \mathrm{mM}$ potassium phosphate gradient, $\mathrm{pH} 7.5$, at a flow rate of $28 \mathrm{ml} / \mathrm{h}$. Enzymatically active fractions were pooled, concentrated and exhaustively dialyzed against $50 \mathrm{mM}$ Tris-HCl, $\mathrm{pH}$ 7.5. Finally, this sample was further fractionated on a Sephacryl S-200 column $(2 \times 160 \mathrm{~cm}$; Pharmacia) equilibrated against the same buffer as used for dialysis and developed at a flow rate of $50 \mathrm{ml} / \mathrm{h}$. Fractions containing enzyme activity were concentrated to $10 \mathrm{ml}$ and stored at $4^{\circ} \mathrm{C}$. Under these conditions, the purified enzyme was stable for over 2 months. A summary of the purification procedure is shown in Table 1. The enzyme activity was monitored using as substrate the intramolecularly quenched fluorogenic peptide derived from BK, containing the oaminobenzoyl (Abz) and ethylenediamine 2,4-dinitrophenyl (EDDnp) groups at the amino- and carboxyl-terminal amino acid residues, Abz-Arg-Pro-Pro-Gly-Phe-Ser-ProPhe-Arg-EDDnp, as previously described $(18,19)$. Protein content was evaluated by the method of Bradford (20).

The purity of the enzyme was demonstrated by analytical polyacrylamide gel electrophoresis: i) under nondenaturing conditions, showing a single band of protein which coincided with the enzyme activity, and ii) 
under denaturing conditions (heating at $100^{\circ} \mathrm{C}$ in the presence of $1 \%$ SDS and $10 \%$ ß-mercaptoethanol), also showing a single protein band with an apparent $\mathrm{M}_{\mathrm{r}}$ of $85 \mathrm{kDa}$ (data not shown).

The effects of various classical protease inhibitors on the enzyme activity were tested (data not shown). The serine- (phenylmethanesulfonyl fluoride, soybean trypsin inhibitor, N-tosyl-1-phenylalanine chloromethylketone and aprotinin), cystine- (p-chloromercuribenzenesulfonic acid and N-ethylmaleimide) and carboxyl- (pepstatin and guanidylethylmercaptosuccinic acid) protease inhibitors, at $1 \mathrm{mM}$ concentration, did not inhibit the enzyme activity. However, metalloprotease inhibitors such as EDTA, EGTA and $o$ phenanthroline at $1 \mathrm{mM}$ concentration fully inhibited the enzyme activity, suggesting that it is a metalloendopeptidase. Furthermore, phosphoramidon and captopril, specific inhibitors of neutral endopeptidase (EC 3.4.24.11) and angiotensin-converting enzyme (EC 3.4.15.1), respectively, did not inhibit enzyme activity at micromolar concentrations.

The metalloendopeptidase hydrolyzed the $\mathrm{Pro}^{7}-\mathrm{Phe}^{8}$ bond of bradykinin (Figure 1B) and the $\mathrm{Ser}^{25}-\mathrm{Tyr}^{26}$ bond of atrial natriuretic peptide (Figure 1A). The Km values for the enzyme-catalyzed hydrolysis of BK and ANP were $5 \mu \mathrm{M}$ and $10 \mu \mathrm{M}$, respectively (data not shown). These results indicate the high affinity of the metalloendopeptidase for the peptide hormones studied, while no cleavage was produced in other peptide hormones such as vasopressin, oxytocin or Met- and Leu-enkephalin (data not shown).

The present results demonstrate that the new metalloendopeptidase isolated from human liver is distinct from NEP and ACE, since specific inhibitors for both had no effect on its activity. Furthermore, this liver metalloendopeptidase also differs from another liver bradykinin-inactivating endopeptidase similar to the thimet-endopeptidase (EC 3.4.24.15) since they hydrolyze distinct peptide bonds of BK, i.e., the $\mathrm{Pro}^{7}-\mathrm{Phe}^{8}$ and Phe ${ }^{5}$-Ser ${ }^{6}$ bonds, respectively (21). Recently, BK metabolism was investigated in the intact rat liver and $7 \%$ of all BK fragments formed during a single transhepatic passage were from cleavage of the $\mathrm{Pro}^{7}-\mathrm{Phe}^{8}$ bond (22). However, the liver endopeptidase responsible for this activity was not identified and the new metalloendopeptidase presented in this study may be a candidate for the cleavage of the $\mathrm{Pro}^{7}-\mathrm{Phe}^{8}$ bond of $\mathrm{BK}$ in the liver.

On the other hand, this liver metalloendopeptidase described here showed similarities with the peptide hormone-inactivating

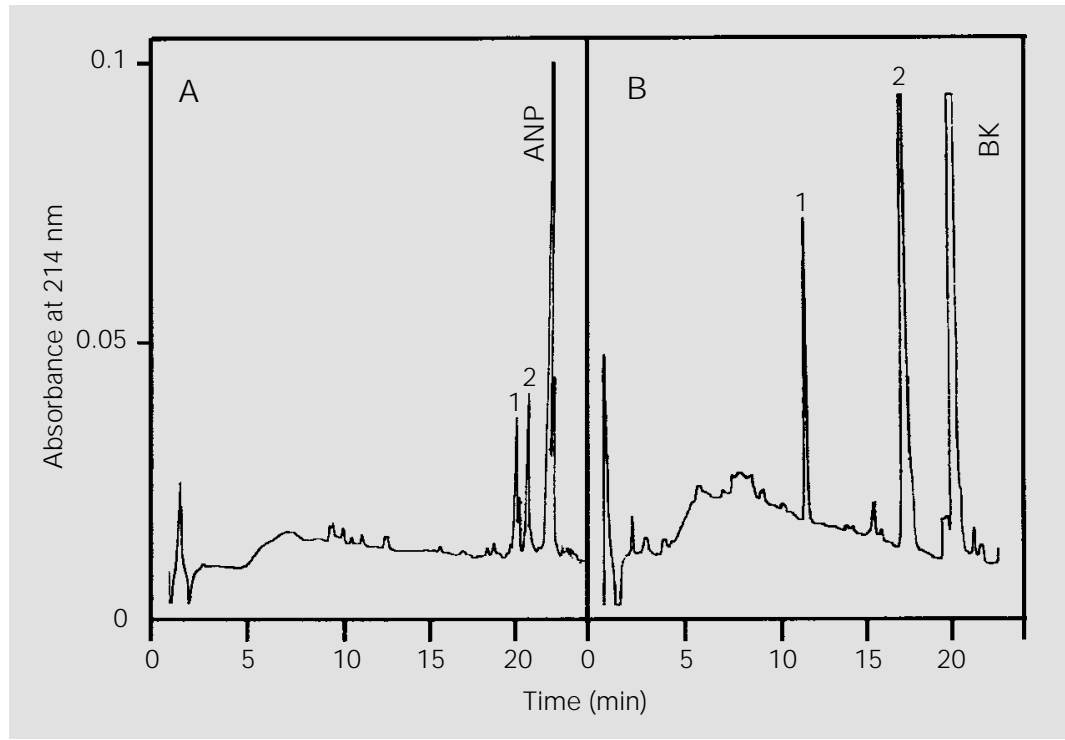

Figure 1 - A, HPLC elution profile of atrium natriuretic peptide (ANP)(5-28) products after hydrolysis by a purified liver metalloendopeptidase. The substrate $(20 \mathrm{nmol})$ was incubated with $15 \mu \mathrm{l}$ of the purified enzyme in a final volume of $30 \mu \mathrm{l} 50 \mathrm{mM}$ Tris-HCl buffer, $\mathrm{pH}$ 7.5, for $30 \mathrm{~min}$ at $37^{\circ} \mathrm{C}$. The reaction was stopped by heating the mixture at $100^{\circ} \mathrm{C}$ for $5 \mathrm{~min}$ followed by centrifugation at $10,000 \mathrm{~g}$ for $10 \mathrm{~min}$. The supernatant fraction was injected into an HPLC column (Nucleosyl $5 \mu \mathrm{m} \mathrm{C}_{18} 145 \times 4.5 \mathrm{~mm}$ ) eluted with a 0-50\% gradient of acetonitrile containing $0.05 \%$ TFA over a period of $35 \mathrm{~min}$ at a flow rate of $1 \mathrm{ml} / \mathrm{min}$. Fragments were identified by amino acid composition: 1 and 2 are the 26-28 and 5-25 fragments of $\mathrm{ANP}_{(5-28)}$, respectively. B, HPLC elution profile of bradykinin (BK) products after hydrolysis by purified liver metalloendopeptidase. The substrate $(20 \mathrm{nmol})$ was incubated with $15 \mu \mathrm{l}$ of the purified enzyme in a final volume of $30 \mu \mathrm{l} 50 \mathrm{mM}$ Tris- $\mathrm{HCl}$ buffer, $\mathrm{pH}$ 7.5 , for $30 \mathrm{~min}$ at $37^{\circ} \mathrm{C}$. The reaction was stopped by heating the mixture at $100^{\circ} \mathrm{C}$ for $5 \mathrm{~min}$ followed by centrifugation at $10,000 \mathrm{~g}$ for $10 \mathrm{~min}$. The supernatant fraction was injected into an HPLC column (Nucleosyl $5 \mu \mathrm{m} \mathrm{C}_{18} 145 \times 4.5 \mathrm{~mm}$ ) eluted with a 2-30\% gradient of acetonitrile containing $0.05 \%$ TFA over a period of $35 \mathrm{~min}$ at a flow rate of $1 \mathrm{ml} / \mathrm{min}$. Fragments were identified by amino acid composition: 1 and 2 are the R-P-P-G and F-S-P-F$R$ fragments of $B K$, respectively. 
endopeptidase (PHIE) isolated from Xenopus laevis skin exudate (23) and with the metalloendopeptidase isolated from human neuroblastoma NB-OK-1 cells (17). Both enzymes also cleaved the $\mathrm{Pro}^{7}-\mathrm{Phe}^{8}$ bond of bradykinin and the $\mathrm{Ser}^{25}-\mathrm{Tyr}^{26}$ bond of atrial natriuretic peptide and exhibited the metalloendopeptidase character. Furthermore, the high affinity of the liver metalloendopeptidase for BK $(\mathrm{Km}=10 \mu \mathrm{M})$ and $\mathrm{ANP}(\mathrm{Km}=$ $5 \mu \mathrm{M})$ is similar to that of PHIE and human neuroblastoma endopeptidase, suggesting that it may play a physiological role in the degradation of these circulating hypotensive peptide hormones. Finally, this study reinforces the idea that the liver, similar to the lung and kidney, may also play an important role in the physiological degradation of the circulating hormones BK and ANP.

In conclusion, although further studies are necessary to elucidate the primary structure of this liver endopeptidase described here, PHIE and neuroblastoma endopeptidase, these results, taken as a whole, suggest that these enzymes may represent members of a novel endopeptidase family involved in the physiological degradation of BK and ANP.

\section{References}

taneously hypertensive rats. American J ournal of Hypertension, 3: 622-627.

1. Ananda-Srivasta MB \& Trachet GJ (1993). Atrial natriuretic factor receptors and signal transduction mechanisms. Pharmacological Reviews, 45: 455-497.

2. Mombouli J V \& Vanhoutte PM (1995). Kinins and endothelial control of vascular smooth muscle. Annual Review of Pharmacology and Toxicology, 35: 679-705.

3. Volpe M (1991). Atrial natriuretic factor in the control of circulatory homeostasis. In: Adnot S, Cantin M \& Pierre-Etienne C (Editors), Atrial Natriuretic Factor: Physiological and Clinical Aspects. Flammarion Médecine-Sciences, Paris.

4. Bhoola $K D$, Figueroa $C D \&$ Worthy $K$ (1992). Bioregulation of kinins, kallikreins, kininogens and kininases. Pharmacological Reviews, 44: 1-80.

5. Ruskoaho H (1992). Atrial natriuretic peptide: synthesis, release, and metabolism. Pharmacological Reviews, 44: 479-602.

6. Skidgel RA (1992). Bradykinin-degrading enzymes: structure, function and potential roles in cardiovascular pharmacology. J ournal of Cardiovascular Pharmacology, 20 (Suppl 9): S4-S9.

7. Linz W, Wiemer G, Gohlke P, Unger T \& Schölkens BA (1995). Contribution of kinins to the cardiovascular actions of angiotensin-converting enzyme inhibitors. Pharmacological Reviews, 47: 25-49.

8. Koepke J P, Tyler LD, Trapani AJ , Bovy PR , Spear KL, Olins GM \& Blaine EH (1989). Interaction of non-guanylate cyclase-linked atriopeptin receptor ligand and endopeptidase inhibitor in conscious rats. J ournal of Pharmacology and Experimental Therapeutics, 249: 172-176.

9. Koepke J P, Tyler LD, Mehta PP, Olins GM, Trapani AJ , Hartuppe DA, Bovy PR, Spear KL \& Blaine EH (1990). Atriopeptin regulation and renal function in conscious spon-
10. Seymour AA, Norman J A, Assad MM, Fennell SA, Abboa Offei B, Little DK, Kratunis VJ, Delaney NG, Hunt JT \& Di Donato G (1991). Possible regulation of atrial natriuretic factor by neutral endopeptidase 24.11 and clearance receptors. J ournal of Pharmacology and Experimental Therapeutics, 256: 1002-1009.

11. Vemulapalli S, Chiu PJ , Brown A, Griscti K \& Sybertz EJ (1991). The blood pressure and renal responses to $\mathrm{SCH} 34826$, a neutral metalloendopeptidase inhibitor, and CANF (4-23) in Doca-salt hypertensive rats. Life Sciences, 49: 383-391.

12. Kukkonen $P$, Vuolteenaho $O \&$ Ruskoaho H (1992). Basal and volume expansionstimulated plasma atrial natriuretic peptide concentration and hemodynamics in conscious rats: effects of SCH 39.370, an endopeptidase inhibitor, and C-ANF 4-25, a clearance receptor ligand. Endocrinology, 130: 755-765.

13. Koepke J P, Tyler LD, Blehm DJ , Schuh J R \& Baline EH (1990). Chronic atriopeptin of arterial pressure in conscious hypertensive rats. Hypertension, 16: 642-647.

14. Ruskoaho H (1992). Atrial natriuretic peptide: synthesis, release, and metabolism. Pharmacological Reviews, 44: 479-602.

15. J ohnson GR, Arik L, Pitts J r B \& Foster CJ (1990). Rapid receptor mediated catabolism of ${ }^{125}$ I-atrial natriuretic factor by vascular endothelial cells. Biochemical J ournal, 268: 771-776.

16. Toll L, Brandt SR, Olsen CM, J udd AK \& Almquist RG (1991). Isolation and characterization of a new atrial peptide-degrading enzyme from bovine kidney. Biochemical and Biophysical Research Communications, 175: 886-893.
17. Delport C, Carvalho KM, Leseney AM, Winand J , Christophe J \& Cohen P (1992). A new metalloendopeptidase from human neuroblastoma NB-OK-1 cells which inactivates atrial natriuretic peptide by selective cleavage at the Ser ${ }^{123}$-Phe ${ }^{124}$ bond. Biochemical and Biophysical Research Communications, 182: 158-164.

18. Chagas J R, J uliano L \& Prado ES (1990). Intramolecular quenched fluorogenic tetrapeptide substrate for tissue and plasma kallikreins. Analytical Biochemistry, 191: 419-425.

19. Oliveira MCF, Hirata IY, Chagas J R, Boschov P, Gomes RAS, Figueredo AFS \& J uliano L (1992). Intramolecularly quenched fluorogenic peptide substrate for human renin. Analytical Biochemistry, 203: 39-46.

20. Bradford MM (1976). A rapid and sensitive method for the quantitation of microgram quantities of protein utilizing the principle of protein-dye binding. Analytical Biochemistry, 72: 248-254.

21. Molina HM, Carmona AK, Kouyoumdjian M, Borges DR \& J uliano L (1996). Liver bradykinin-inactivation-endopeptidase is similar to the metalloendopeptidase (EC 3.4.24.15). Immunopharmacology, 32: 176-179.

22. Griswold J A, Beall CV, Backer J r CR, Little GH \& Behal FJ (1996). Bradykinin metabolism in the liver and lung of the rat. J oumal of Surgery Research, 66: 12-20.

23. Carvalho KM, J oudiou C, Bousseta $\mathrm{H}$, Leseney AM \& Cohen P (1992). A peptide hormone-inactivating endopeptidase in Xenopus laevis skin secretions. Proceedings of the National Academy of Sciences, USA, 89: 84-88. 